\title{
INISIASI PENGEMBANGAN PERTANIAN URBAN UNTUK PENGUATAN KETAHANAN PANGAN PADA ERA PANDEMI DI JATIROTO
}

\section{INITIATION OF URBAN AGRICULTURAL DEVELOPMENT TO STRENGTHEN FOOD SECURITY IN PANDEMIC ERA IN JATIROTO}

\author{
R F Taufik ${ }^{1 a}$, Y Nurdian ${ }^{1}$ \\ ${ }^{1}$ Program Studi Agroteknologi, Fakultas Pertanian Universitas Jember \\ ${ }^{a}$ Korespondensi:Rahadian Falqi Taufik; E-mail: falqi67@gmail.com \\ (Diterima: 07-08-2020; Ditelaah: 08-09-2020; Disetujui: 26-10-2020)
}

\begin{abstract}
Hydroponics is a plant cultivation technique by changing the soil growing media to water growing media. Hydroponics can reduce the negative impact felt by the community due to the Covid19 pandemic because they often feel the impact of government policies to just stay at home so they feel Cabin Fever. Hydroponic farming during a pandemic is an activity that can minimize the negative activities carried out by the community to be turned into positive things and also minimize the community to buy vegetables in the market so that they do not feel physical contact with other communities and can harvest vegetables according to the heart's desire. A situation like this happened in Jatiroto Village, Jatiroto District, Lumajang Regency due to a covid-19 pandemic like this. Community empowerment to farm at home has been carried out using the method of providing materials, assistance from sowing seeds to harvesting. As a result, every community can be hydroponic with a variety of planted vegetables.
\end{abstract}

Keywords : Hydroponics, Covid19, and Cabin Fever.

\begin{abstract}
ABSTRAK
Hidroponik adalah salah satu teknik budidaya tanaman dengan merubah media tanam tanah ke media tanam air. Hidroponik dapat mengurangi dampak negatif yang dirasakan masyarakat akibat adanya pandemi Covid19 karena terlalu sering merasakan dampak yang dari kebijakan pemerintah untuk diam dirumah saja sehingga merasakan Cabin Fever. Bertani hidroponik pada masa pandemi adalah kegiatan yang dapat meminimalisir dari kegiatan negatif yang dilakukan masyarakat untuk diubah menjadi hal positif dan juga meminimalisir masyarakat untuk membeli sayur dipasar sehingga tidak merasakan kontak fisik bersama masyarakat lain dan dapat memanen sayuran sesuai keinginan hati. Situasi seperti ini terjadi di desa Jatiroto, Kecamatan Jatiroto, Kabupaten Lumajang akibat adanya pandemi covid-19 seperti ini. Pemberdayaan masyarakat untuk bertani di rumah telah dilakukan dengan metode pemberian materi, Pendampingan mulai benih disemai hingga panen. Hasilnya, setiap masyarakat dapat berhidroponik dengan berbagai tanaman sayuran yang ditanam.
\end{abstract}

Kata Kunci : Hidroponik, Covid19, dan Cabin Fever. 
Taufik, R.F., dan Wachdijono. (2020). Inisiasi Pengembangan Pertanian Urban Untuk Penguatan ketahanan Pangan Pada Era Pandemi di Desa Jatiroto. Jurnal Qardhul Hasan : Media Pengabdian kepada Masyarakat, 6(2), 114-120.

\section{PENDAHULUAN}

Desa Jatiroto Adalah salah satu desa kecil yang ada di Kecamatan Jatiroto dan berada di ujung bagian timur Kabupaten

Lumajang. Pertanian saat ini sedang mengalami penurunan akibat berlihnya fungsi lahan oleh masyarakat yang berawal dari lahan pertanian menjadi lahan permukiman dan juga industri sehingga berdampak bagi sebagian petani yaitu kepemilikan lahan pertanian semakin sempit serta terdapat kendala pada saat ini yaitu pandemi covid19 yang sedang mewadah di seluruh daerah bahkan seluruh negara mengalami dampak negatif yang dirasakan oleh masyarakat salah satunya menurunnya hasil produksi pertanian akibat banyak petani yang ketakutan untuk pergi kesawah dikarenakan pandemi ini yang sangat cepat menular dari masyarakat satu ke masyarakat lainnya. Sehubungan dengan menurunnya hasil pertanian dalam program KKN Back To Village ini memberi program bertani dirumah dengan sistem pertanian urban.

Sebelah selatan berbatasan dengan Kecamatan Rowokangkung, Sebelah barat berbatasan dengan kecamatan Randuagung dan Kecamatan Sukodono, dan Sebelah Utara Berbatasan dengan Kecamatan Randuagung. Desa Jatiroto adalah salah satu desa yang memiliki potensi berupa Pabrik Gula Terbesar yang cukup dikenal masyarakat yaitu Pabrik Gula Djatiroto yang termasuk bagian dari PTPN XI. Masyarakat Desa Jatiroto bermata pencaharian sebagai Karyawan PG, Pegawai Negeri Sipil (PNS) Pedagang dan juga petani.

Pertanian saat ini sedang mengalami penurunan akibat berlihnya fungsi lahan oleh masyarakat yang berawal dari lahan pertanian menjadi lahan permukiman dan juga industri sehingga berdampak bagi sebagian petani yaitu kepemilikan lahan pertanian semakin sempit serta terdapat kendala pada saat ini yaitu pandemi covid19 yang sedang mewadah di seluruh daerah bahkan seluruh negara mengalami dampak negatif yang dirasakan oleh masyarakat salah satunya menurunnya hasil produksi pertanian akibat banyak petani yang ketakutan untuk pergi kesawah dikarenakan pandemi ini yang sangat cepat menular dari masyarakat satu ke masyarakat lainnya. Sehubungan dengan menurunnya hasil pertanian dalam program KKN Back To Village ini memberi program bertani dirumah dengan sistem pertanian urban.

Pertanian urban adalah suatu kegiatan budidaya pertanian yang dilaksanakan pada daerah yang memiliki keterbatasan lahan seperti di wilayah perkotaan. Pertanian urban dilakukan dan menjadi gaya hidup masyarakat perkotaan dengan tujuan untuk menjaga kesehatan, dan kebutuhan pangan mereka melalui hasil panen dari pertanian urban tersebut. Adapun tantangan yang akan dihadapi dalam menunjang pengembangan pertanian urban seperti luasan lahan, pasokan sinar matahari, pasokan air bersih dan sirkulasi udara, pencemaran logam berat, dan keterbatasan pengetahuan mengenai pertanian urban (BTTP Jakarta, 2016). Salah satu pertanian urban yang diterapkan adalah Hidroponik dimana pengaplikasian hidroponik merupakan alternatif pertanian yang lebih efisien tanpa media tanah pada saat pandemi Covid19 (Sumarni dkk, 2017).

Menurut Wahyuningsih dkk (2017), pertanian hidroponik merupakan pertanian modern yang dikembangkan dengan mengganti media tanam yang awalnya adalah tanah kemudian diganti dengan air. Nutrisi yang digunakan juga dalam bentuk cair sehingga mudah diserap oleh tanaman. Penerapan Pertanian hidroponik sudah mulai dilakukan oleh masyarakat Jatiroto dalam skala besar dan juga skala kecil dengan menggunakan bahan bekas. 
Penggunaan hidroponik pada saat pandemi covid19 bertujuan untuk menambah kegiatan positif yang dilakukan masyarakat agar lebih produktif dan hasil yang di hasilkan dapat dikonsumsi masyarakat itu sendiri ataupun dijual ke masyarakat lain sehingga dapat meningkatkan ekonomi masyarakat Jatiroto. Terdapat beberapa jenis pada sistem pertanian hidroponik yaitu Wick System (sistem sumbu), Nutrien Film Technique (NFT), Floating system (Rakit apung), Ebb and Flow (Hidroponik pasang surut), Drip Irrigation (Irigasi Tetes), Aeroponik (Bercocok tanam di udara), Bioponics, Sistem DWC (Hendra dan Andoko, 2014). Pertanian Hidroponik juga dapat menguatkan ketahanan pangan masyarakat pada masa pandemi Covid19.

Ketahanan pangan adalah ketersediaan pangan dan kemampuan masyarakat untuk memenuhi kebutuhan pangan bukan hanya untuk satu keluarga melainkan seluruh masyarakat yang merasakan dampak disaat pandemi seperti ini sehingga penting untuk memenuhi gizi dan nutrisi masyarakat. Ketahanan pangan pada saat ini menjadi persoalan besar bagi bangsa Indonesia karena pemerintah sendiri sudah melarang masyarakat keluar rumah dan hanya diam dirumah (Stay At Home) sehingga banyak masyarakat yang harus mendapatkan pasokan makanan tanpa harus keluar rumah seperti menanam di perkarangan rumah pada sistem hidroponik sehingga masyarakat bisa menghasilkan sayuran dan buah yang di tanam untuk kebutuhan sehari- hari dalam kegiatan kkn ini back to village Universitas Jember ini di wajibkan mahasiswa terjun untuk berpartisipasi secara langsumg di desanya untuk mengatasi permasalahan yang sedang di hadapi. Kepala Desa jatiroto juga menerima dan menyetujui akan program yang dijalankan serta mahasiswa juga diberi program yang sesui dengan pengetahuan dan kualitasnya untuk dijalankan di desa jatiroto ini. Mahasiswa merangkul masyarakat yang ingin belajar mengenai hidroponik melalui dari pembuatan instalasi, penyemaian hingga panen.

\section{MATERI DAN METODE}

Metode pemberdayaan di Desa Jatiroto dilakukan bertahap pada tiap minggunya meliputi : Identifikasi masalah : Keadaan umum sasaran, masalah yang dialami masyarakat, 2. Alternatif Pemecahan masalah, 3.

Pelaksanaan Kegiatan.

\section{Identifikasi Keadaan Umum Sasaran}

Sasaran kegiatan ini adalah warga masyarakat Desa Jatiroto yang saat ini sedang mengalami Cabin Fever akibat adanya pandemi Covid19 dan juga kebijakan pemerintah mengenai mudahnya Covid19 ini menular sehingga pemerintah mengeluarkan kebijakan semua masyarakat harus diam dirumah saja (stay at home).

\section{Identifikasi Masalah yang Dialami Masyarakat.}

Identifikasi masalah yang dilakukan dengan metode wawancara dengan kepala desa dan pengamatan secara langsung ke rumah masyarakat sasaran. Faktor penghambat : (A) Sumber daya alam : Kondisi yang dialami masyarakat sekaraang adalah pada masa pandemi covid19, (B) Sumber daya manusia: masyarakat belum menerapkan pertanian urban. Faktor penguat : (A) Sumber daya alam : ada pekarangan rumah walaupun terbatas, barang barang bisa menggunakan bahan bekas. (B) Sumber daya manusia : jumlah masyarakay usia produktif yang tinggi, terdapat sarana pendidikan dan siswa mulai Paud, TK, SD, SMP, SMA dan sederajat, terdapat keinginan positif memutus tali rantai covid19.

\section{Alternatif pemecahan masalah}

Dengan diketahui faktor penghambat dan faktor penguatan dalam masalah masyarakat di Desa Jatiroto, Kecamatan Jatiroto, Kabupaten Lumajang. Maka program kerja yang akan dipraktekkan harus dapat dilaksanakan dalam jangka waktu yang relatif singkat dan memiliki manfaat langsung bagi masyarakat sasaran, maka fokus yang dipilih adalah 
mengoptimalkan pekarangan rumah dengan berhidroponik. Kegiatan ini merupakan mitigasi dari pertanian konvensional sehingga dapat mewujudkan masyarakat yang sehat, sejahtera dan mewujudkan desa berbasis edukasi urban farming, serta memutus rantai covid19.

\section{Pelaksanaan Program Kerja}

Kegiatan ini dilaksanakan secara bertahap. Tahap pertama dilakukan pada minggu pertama pada tanggal 1-7 Juli 2020 yaitu pemberian materi terkait bahaya covid19 dan hidroponik secara umum. Pada minggu ke-2 dilaksanakan tanggal 8-14 yaitu Pendampingan Instalasi Hidroponik dan Penyemaian. Pada minggu ke-3 tanggal 1521 yaitu Pembibitan tanaman hidroponik dan juga melaksanakan Webinar 1 dengan tema "Pelatihan Pembuatan Instalasi Hidroponik dan Nutrisi AB Mix" yang diikuti oleh 70 peserta. Pada minggu ke-4 tanggal 22-28 yaitu pembuatan nutrisi dan pindah tanam dan melaksanakan kelas secara offline.

Pada minggu ke-5 tanggal 29 Juli-04 Agustus yaitu Panen hasil budidaya Hidroponik dan melaksanakan Webinar ke 2 dengan tema "Pelatihan Hidroponik Sebagai Kegiatan Disaat Pandemi Covid-19" yang diikuti oleh 146 peserta. Untuk minggu ke 6 dan 7 yaitu melakukan evaluasi dan laporan. Persiapan alat dan bahan terdiri atas : Bak, Styrofoam, gergaji besi, cutter, penggaris, spidol, kawat berlubang, nettpot, kain flanel, nutrisi AB Mix, Benih, Rockwool, Air, TDS/EC Meter, pH Meter. Sedangkan cara pembuatan instalasi hidroponik sistem wick menurut Puspasari dkk (2017) (Gambar 1) dan Pembuatan Nutrisi AB Mix (Gambar 2). Bibit yang digunakan yaitu kangkung, sawi pakcoy, selada, dan seledri. Gambar 1. Intalasi Hidroponik Sistem wick.

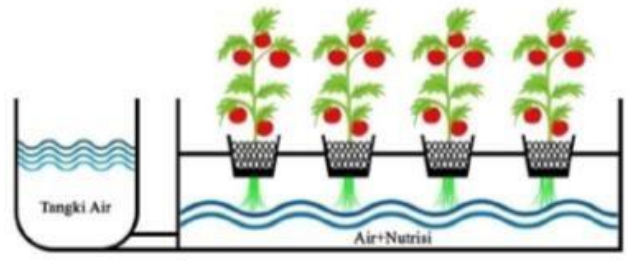

Gambar 2. Materi Wabinar 1
Pembuatan Nutrisi AB Mix
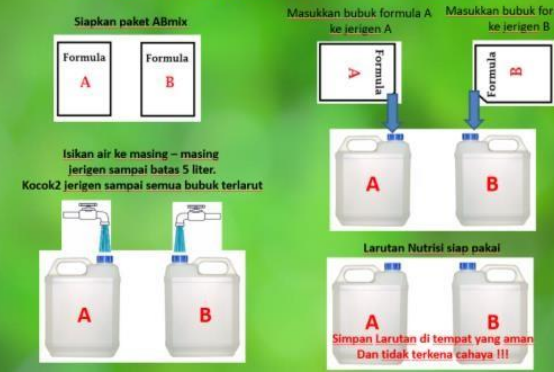

Tahapan Pembuatan Instalasi Hidroponik Menyiapkan alat dan bahan berupa Styrofoam, cutter, penggaris, kawat berlubang, kompor untuk memanaskan kawat. Potong styrofoam sesuai ukuran bak, beri tanda menggunakan penggaris dan spidol dengan jarak $20 \mathrm{~cm}$ kemudian panaskan kawat pelubang menggunakan kompor dan lubangi sesuai ukuran yang telah diukur. Masukkan styrofoam ke bak dan pasang nettpot ke dalam lubang dan instalasi hidroponik sistem wick siap digunakan.

\section{Proses Pembuatan Nutrisi AB Mix}

Siapkan paket nutrisi AB Mix, larutkan tiap nutrisi A dan B ditempat terpisah pada 250 $\mathrm{mL}$ air, aduk hingga homogen, tambahkan air hingga $500 \mathrm{~mL}$, aduk hingga merata, dan Nutrisi AB Mix Siap diaplikasikan.

\section{HASIL DAN PEMBAHASAN}

Kegiatan pengabdian masyarakat dengan masyarakat sasaran yang terdampak Covid19 dan juga masyarakat Desa Jatiroto, Kecamatan Jatiroto, Kabupaten Lumajang yang dilaksanakan selama 45 hari.

Gambar 3. Sosialisasi Covid 19 dan Hidroponik.

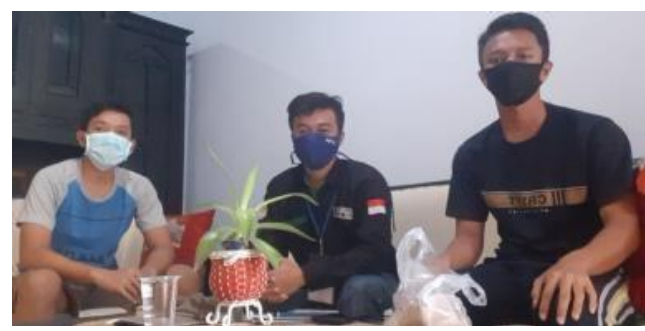

Gambar 4. Pembibitan 


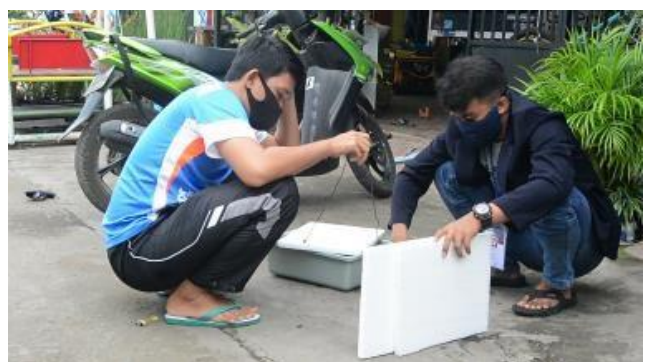

Gambar 5. Pembuatan instalasi hidroponik dan nutrisi $\mathrm{AB}$ MIX.

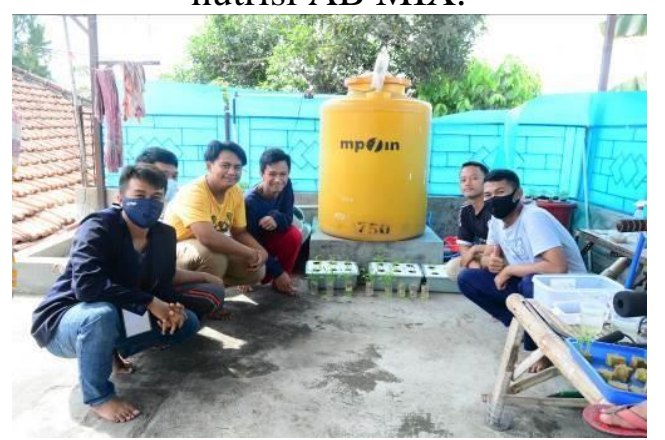

Gambar 6. Panen

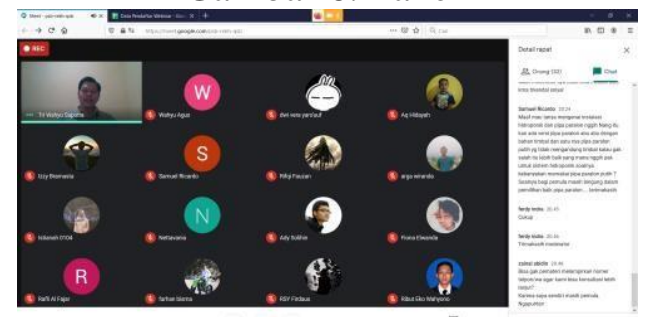

a

Gambar 7. Pengukuran Nutrisi AB MIX

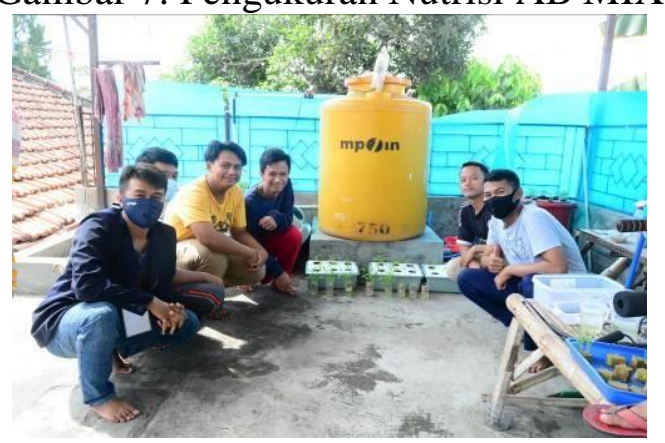

Gambar 8. Dokumentasi Webinar 2

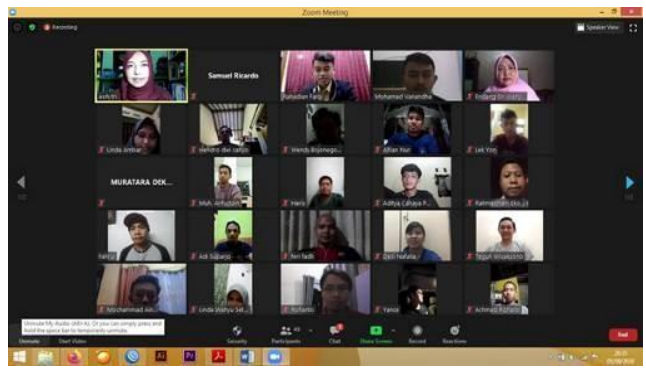

\section{PEMBAHASAN}

Kegiatan pengabdian kepada masyarakat dengan sasaran masyarakat yang terdampak Cabin Fever akibat adanya
Covid19 yang dirasakan masyarakat Seluruh Indonesia terutama masyarakat Jatiroto. Berdasarkan hasil survei yang dilakukan, program kegiatan di Desa Jatiroto telah melaksanakan beberapa kegiatan yaitu berawal dari Kegiatan Mahasiswa KKN Back To Village telah melakukan komunikasi dengan Kepala desa Jatiroto yaitu Bapak Nujum untuk meminta izin dan dukungan dalam segala kegiatan yang akan dilaksanakan. Melalui wawancara dan diskusi dengan Bapak Nujum selaku Kepala Desa jatiroto untuk menyusun perencanaan kegiatan dan konsep pelaksanaan diantaranya : jenis Kegiatan dan jadwal Pelaksanaan Kegiatan.

Tahap pelaksanaan dilaksanakan oleh mahasiswa secara individu karena KKN Back To Village dilakukan secara Individu tanpa berkelompo sehinggan kegiatan KKN ini dilaksanakan secara Individu dengan Tema Program Inovasi Teknologi/Informasi Dalam Penangan Covid19. Berdasarkan data yang didapatkan, dengan mengkombinasakan program kerja yang akan dilakukan selama 45 hari kedepan di Desa Jatiroto yaitu Sistem Hidroponik dapat menjadi pereda cabin fever. Program tersebut bertujuan supaya bisa bermanfaat bagi masyarakay dan juga bisa membantu mengatasi permasalahan masyarakat di Desa Jatiroto.

Hidroponik adalah cara budidaya tanaman dengan memanfaatkan air tanpa menggunkan media tanah dan menekan pertumbuhan kebutuhan nutrisi tanaman. Sistem hidroponik tidak banyak membutuhkan air dibandingkan dengan budidaya yang menggunkaan media tanah.Nutrisi yang dibutuhkan tanaman hidroponik sama dengan tanaman budidaya konvesional berupa hara essensial makro dan mikro (Wahyuningsih dkk, 2016). Hidroponik mempunyai nilai tambah berupa hasil produksi yang lebih bersih dan higinies. Hidroponik juga sangat penting dalam pertanian presisi sebab mampu menyatukan pengentahuan yang diperoleh melalui teknik budidaya tradisional yang mampu dipaduka dengan otomatisasi 
teknologi. hidroponik merupakan salah satu teknik pertanian presisi yang melekat dengan tanaman tumbuh menggunakan larutan air tanpa menggunakan tanah (Ramos et al, 2019). Nutrisi hidroponik yang umumnya digunakan untuk budidaya yaitu nutrisi AB Mix Nutrisi AB Mix merupakan larutan hidroponik yang mengandung unsur hara mikro dan makro yang digunakan untuk mendukung pertumbuhan tanaman. Stok A mengandung hara N, K, Ca dan Fe, sedangkan stok B mengandung unsur hara $\mathrm{P}$ dan hara mikro (Setiawan., 2017). Nutrisi $\mathrm{AB}$ mix yang tidak memiliki kandungan $\mathrm{C}, \mathrm{H}$, $\mathrm{O}$ dan $\mathrm{Cl}$ menyebabkan pertumbuhan tanaman kurang maksimal seperti tanaman membutuhkan oksigen dalam siklusnya. Komposisi nutrisi yang diberikan pada setiap tanaman yang dibudidayakan hampir sama. Nutrisi juga sangat mudah didapatkan baik dalam bentuk kemasan pabrik maupun dibuat dengan cara sendiri. Nutrisi buatan pabrik seperti nutrisi $A B$ mix yang terdiri dari serbuk A dan B yang dilarutkan dengan air kemudian diencerkan. Pengenceran larutan $\mathrm{AB}$ mix dan air harus disesuaikan dengan kebutuhan tanaman. Konsentrasi nutrisi $\mathrm{AB}$ mix dari pabrik mampu menghasilkan pertumbuhan tanaman yang baik dibandingkan dengan nutrisi lainnya selain itu mudah digunakan.

KKN Back To Village ini melaksanakan program hidroponik yang dilakukan mulai dari pembuatan instalasi hidroponik dan Nutrisi AB Mix hingga menghasilkan tanaman yang dipanen. Melalui hasil panen tersebut masyarakat diharapkan meminimalisir pergi ke pasar dan juga dapat meningkatkan kesejahteraan masyarakat dan juga meningkatkan ekonomi masyarakat Jatiroto melalui Covid19. Sehingga melalui kegiatan KKN Back To Village selama 45 hari ini diharapkan menjadi kegiatan yang bermanfaat bagi masyarakat untuk masa yang akan datang.

Evaluasi kegiatan dilaksanakan untuk mengatahui keberhasilan yang telah dilakukan pada Program kerja selama 45 hari. Hasil pelaksanaan kegiatan pengabdian kepada masyarakat ini secara garis besar mampu menyadarkan masyarakat akibat dampak pandemi saat ini.setelah dilakukan evaluasi oleh kepala desa Jatiroto, beliau juga menyampaikan terimakasih dengan adanya program KKN Back To

Village ini dapat menjadi ilmu yang bermanfaat dan sumber pendapatan bagi masyarakat selama pandemi ataupun setelah pandemi ini usai dan juga beliau sudah merencanakan untuk membangun Desa Tangguh

Covid19.

\section{KESIMPULAN}

KKN Back To Village ini dilaksanakan akibat adanya Covid 19 ini, karena penyebaran yang begitu pesat sehungga kebijakan instansi melaksanakan KKN ini dilakukan di Desa Sendiri. Pelaksanakan Kegiatan KKN Melalui Pemberdayaan Masyarakat ini Diharap dapat menghasilkan masyarakat yang bisamengembangkan pertanian urban (urban farming) berupa pertanian sistem hidroponik sehingga hasil yang didapatkan bisa dikonsumsi sendiri dan juga bisa meningkatkan ekonomi masyarakat Desa Jatiroto serta meminimalisir masyarakat Desa

Jatiroto untuk tidak pergi ke pasar. Pelaksanaan KKN yang dilakukan selam 45 hari ini memberikan pengaruh positif untuk masyarakat Desa Jatiroto. Hidroponik juga memiliki banyak sistem yang bisadikembangkan seperti Wick System (sistem sumbu), Nutrien Film Technique (NFT), Floating system

(Rakit apung), Ebb and Flow (Hidroponik pasang surut), Drip Irrigation (Irigasi Tetes), Aeroponik

(Bercocok tanam di udara), Bioponics, Sistem DWC.

\section{DAFTAR PUSTAKA}

Balai Pengkajian Teknologi Pertanian. 2016. Pertanian IAARD PRESS:

Jakarta.

C. Ramos, L. Nóbrega, K. Baras and L. Gomes, "Experimental NFT hydroponics 
system with lower energy consumption," 2019 5th Experiment International

Conference (exp.at'19), Funchal (Madeira Island), Portugal, 2019, pp. 102-106.

Hendra, H. A., dan A. Andoko. 2014. Bertanam Sayuran Hidroponik ala Paktani Hydrofarm. Jakarta Selatan: Pustaka.

PT. Agromedia

Puspasari, I., Triwidyastuti, Y., \& Harianto, H. 2017. LP: Otomasi Sistem Hidroponik Wick pada Pembibitan Tanaman Tomat

Ceri.

Setiawan, H. 2017. Kiat Sukses

Budidaya Cabai Hidroponik.

Yogyakarta: HutaMedia.

Sumarni, E., Soesanto, L., Farid, N.,
\& Baroroh, H. N. 2017.

Pertumbuhan dan perkembangan tanaman purwoceng pada budidaya secara hidroponik nutrient film technique (NFT). Jurnal Litbang Provinsi Jawa Tengah, 15(2), 145-151.

Wahyuningsih, A., Fajriani, S., \& Aini, N. 2017. Komposisi nutrisi dan media tanam terhadap pertumbuhan dan hasil tanaman pakcoy (brassica rapa l.) sistem hidroponik. Jurnal Produksi Tanaman, 4(8).

Wahyuningsih, A., S. Fajriani dan N. Aini. 2016. Komposisi Nutrisi dan Media terhadap

Pertumbuhan Hasil Tanaman Pakcoy (Brasicca rapa L.) Sistem Hidroponik. Produksi Tanaman, 4 (8) : 596-601. 